\title{
Defective Bax activation in Hodgkin B-cell lines confers resistance to staurosporine-induced apoptosis
}

\author{
H Kashkar ${ }^{1}$, M Krönke ${ }^{1}$ and JM Jürgensmeier, ${ }^{*, 1}$ \\ 1 Institute for Medical Microbiology, Immunology and Hygiene, University of \\ Köln, Goldenfelsstrasse 19-21, 50935 Köln, Germany \\ * Corresponding author: JM Jürgensmeier, Institute for Medical Microbiology, \\ Immunology and Hygiene, University of Köln, Goldenfelsstrasse 19-21, 50935 \\ Köln, Germany. Tel: +49-221-478-7283; Fax: +49-221-478-7288; \\ E-mail: juergensmeier@uni-koeln.de.
}

Received 9.10.01; revised 10.1.02; accepted 14.1.02

Edited by C Borner

\begin{abstract}
Deregulated apoptosis represents an important hallmark of tumor cells. Here we investigated the induction of cell death signaling pathways in cell lines previously established from patients with Hodgkin's disease. Our data show that Hodgkin's disease derived B-cell lines uniformly proved resistant to staurosporine, a protein kinase $\mathrm{C}$ inhibitor that preferentially stimulates the mitochondrial apoptotic pathway. Contrary to control cell lines, staurosporine failed to induce cytochrome $c$ release from mitochondria in Hodgkin derived B-cells. Correspondingly, activation of caspases was not observed in these cells. In staurosporine-treated Hodgkin cells Bax remained in its inactive state, indicating that these cell lines have a defect in this crucial step in apoptotic signaling upstream of the mitochondria. Our results suggest that the failure to activate Bax might represent a common defect of Hodgkin tumor cells of the B-cell lineage.

Cell Death and Differentiation (2002) 9, 750-757. doi:10.1038/ sj.cdd. 4401024
\end{abstract}

Keywords: apoptosis; cell death; Bcl-2; Bax; mitochondria; tumor; cancer

Abbreviations: Apaf-1, apoptotic protease-activating factor-1; DEVD-afc, DEVD-7-amino-4-trifluoromethyl coumarin; EBV, Epstein-Barr virus; EGTA, ethylene glycol-bi $\beta$-aminoethyl ether; HD, Hodgkin's disease; PBS, phosphate buffered saline; PMSF, phenylmethylsulfonyl fluoride; TNF, tumor necrosis-factor

\section{Introduction}

Proliferative diseases, including tumors, are characterized by accumulation of cells as a result of a disturbed tissue homeostasis. This is partly due to impairments of apoptosis, which is a highly conserved and tightly regulated mechanism of cell death. The principle effectors of apoptotic signaling are caspases, a family of cysteine containing aspartate-specific proteases. Caspases are synthesized as inactive proforms and exist as zymogens in the cytosol. Upon induction of apoptosis caspases are proteolytically cleaved to an active heterodimer. $^{1,2}$ Eventually caspases cleave cellular substrates resulting in the typical morphological hallmarks of apoptosis. ${ }^{3}$ These cellular substrates also include other caspases, resulting in a caspase cascade, with the executioner caspases $-3,-6$, and -7 at its distal end.

Two distinct apoptotic signaling pathways have been identified. The triggering of death domain containing cell surface receptors of the tumor necrosis factor (TNF) - super family results in the recruitment and proteolytic activation of caspase-8, which eventually results in the cleavage and activation of downstream effector caspases. ${ }^{4}$ The second apoptotic signaling pathway involves mitochondria and results in the release of pro-apoptotic factors from mitochondria, such as cytochrome $c$. The released cytochrome $c$ binds to the cytosolic apoptotic proteaseactivating factor-1 (Apaf-1), subsequently activating caspase-9. This apoptosome complex in turn activates downstream executioner caspases. ${ }^{5-7}$

Each step of the apoptotic signaling cascade is under stringent control. Important regulators of apoptotic signaling are the proteins of the Bcl-2 family, consisting of antiapoptotic members such as Bcl-2, but also include proapoptotic members such as Bax. Bax can induce the release of cytochrome $c$ from mitochondria and represents an important relay of the mitochondrial apoptotic pathway and subsequent activation of caspases. ${ }^{7-9}$ In order to induce cytochrome $c$ release, Bax moves from the cytosol to the mitochondria and undergoes a conformational change, by which it gains its pro-apoptotic activity. ${ }^{10-15}$ The underlying mechanisms for the conformational change and the activation of Bax are not yet known. The proapoptotic action of Bax is antagonized by $\mathrm{Bcl}-2$ and $\mathrm{Bcl}-\mathrm{X}_{\mathrm{L}}$, that inhibit the release of cytochrome $c$ from mitochondria. $^{7-9}$

Overexpression of Bcl-2 due to the $\mathrm{t}(14 ; 18)$ chromosomal translocation, which fuses the $b c l-2$ gene to the immunoglobulin enhancer, has been implicated in the pathogenesis of follicular lymphoma. ${ }^{16-18}$ In contrast, the role of Bcl-2 family proteins for the development of Hodgkin's lymphoma is not yet clear. In most cases of classical Hodgkin's disease (HD), Hodgkin-Reed-Sternberg ( $\mathrm{H}-\mathrm{RS}$ ) cells clonally derive from germinal-center B cells. Within their rearranged immunoglobulin genes, somatic mutations were detected converting potentially functional into non-functional immunoglobulin gene rearrangements, which explains why $\mathrm{H}-\mathrm{RS}$ cells do not express a B-cell receptor. ${ }^{19}$ Under physiological conditions, these cells would undergo apoptosis within the germinal center. However, H-RS cells clonally expand, disseminate, and lead to clonal relapse of HD, indicating their resistance to induced programmed cell death through an unknown mechanism. 
Staurosporine induces apoptosis in almost all cells studied through the mitochondrial apoptotic signaling pathway, although the molecular mechanism remained elusive. $^{20,21}$ This prompted us to study Hodgkin B-cell lines with regard to staurosporine-induced cell death. Strikingly, all Hodgkin derived B-cell lines are resistant to staurosporine-induced cell death and the detailed investigation revealed a defect in Bax activation as the underlying mechanism.

\section{Results}

\section{Induction of pro-apoptotic mitochondrial signaling by staurosporine}

Staurosporine has been described as a potent inducer of apoptosis through the mitochondrial pathway. Most tumor cells undergo apoptosis when treated with staurosporine. ${ }^{22}$ The characteristic cascade of staurosporine-induced signaling steps is exemplified by HeLa cells as shown in Figure 1. As an immediate-early event, Bax activation/conformational change can be detected by a $\mathrm{N}$-terminal epitopespecific antibody, $6 \mathrm{~A} 7$, within $30 \mathrm{~min}$ of staurosporine treatment. The $6 \mathrm{~A} 7$ monoclonal antibody recognizes Bax in a conformation with an exposed $\mathrm{N}$-terminus, but not native Bax. ${ }^{11,12,14,15,23}$ Immunoprecipitations were performed on cell lysates obtained by extraction with $1 \%$ CHAPS. Consistent with published reports, lysis with CHAPS did not induce a Bax conformational change in untreated HeLa cells but Bax was in its native conformation and therefore was not immunoprecipitated by anti-Bax $6 \mathrm{~A} 7$ antibody. ${ }^{11,12,14,15}$ The $\mathrm{N}$-terminal epitope of Bax became accessible for $6 \mathrm{~A} 7$ binding after treatment of HeLa cells with staurosporine. Notably, the total amount of Bax protein

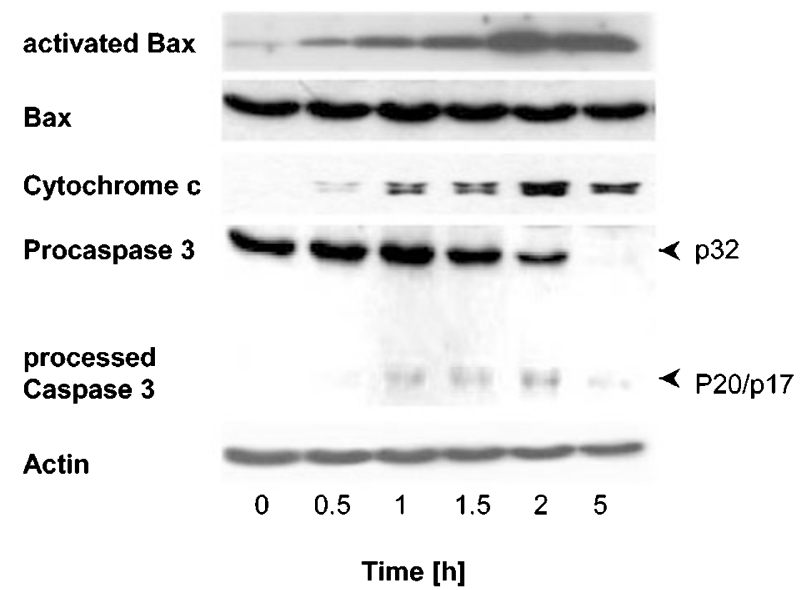

Figure 1 Bax activation, cytochrome $c$ release and caspase activation in HeLa cells. Cells were treated for $5 \mathrm{~h}$ with $1 \mu \mathrm{M}$ staurosporine, aliquots of cell lysates were prepared at the timepoints indicated. Total cell extracts and cytosolic extracts were subjected to SDS-PAGE and Western blotting. Activated Bax was immunoprecipitated in the whole cell extracts with the conformation specific antibody $6 \mathrm{~A} 7$ and subsequently detected by human $\mathrm{Bax}$ antiserum and compared to the total amount of Bax in the lysates. Cytochrome $c$ and caspase- 3 were detected in cytosolic extracts. Reprobing for Actin ensured equal loading remained unchanged, indicating that the increasing fraction of active Bax protein does not correspond to newly synthesized protein. Concomitantly, cytochrome $c$ was released from mitochondria into the cytosol. Activation of caspase-3 occurred with slightly delayed kinetics indicated by the processing into the p20/p17 fragments. These results are in line with the previously proposed sequence of events in mitochondrial apoptosis, where cytochrome $c$ release is induced by the activation of Bax, which eventually results in the activation of caspase- 3 as an executioner caspase.

\section{Staurosporine resistance of Hodgkin derived B-cell lines}

Previously published reports have shown that most tumor cell lines investigated proved sensitive to staurosporine. ${ }^{22}$ However, when we investigated the HD B-cell lines L428, L591, $\mathrm{L} 1236$ and $\mathrm{KMH} 2$, a marked resistance to staurosporine was observed in comparison to control cells (Figure 2). This prompted us to examine the expression of proteins involved in the mitochondrial apoptosis pathway by Western blot analysis (Figure 3 ). Bcl- $\mathrm{X}_{\mathrm{L}}$, one of the major anti-apoptotic proteins, was expressed in all HD B-cell lines tested. In contrast, another anti-apoptotic protein, Bcl-2, was expressed at lower levels in HD B-cell lines compared to control B-cells. The expression of Bax and caspase- 3 was comparable in all cell lines, whereas the Hodgkin B-cells contained slightly less Bak protein compared to the control cells. Taken together, HD Bcells did not reveal an uniform expression pattern of pro- or anti-apoptotic proteins that would explain the staurosporineresistant phenotype.

\section{Defective Bax-activation in HD B-cell lines}

The mere presence or absence of members of the apoptotic pathway does not allow conclusions with respect to intact or defective mitochondrial signaling. This is because rather complex interactions of the proteins of the Bcl-2 family and caspases involving homo- and heterodimerization, conformational changes, and post-translational processing, seem to regulate the mitochondria-associated apoptosis. To test for putative defects in the mitochondrial apoptotic pathway, HD B-cell lines were therefore scrutinized for the character-

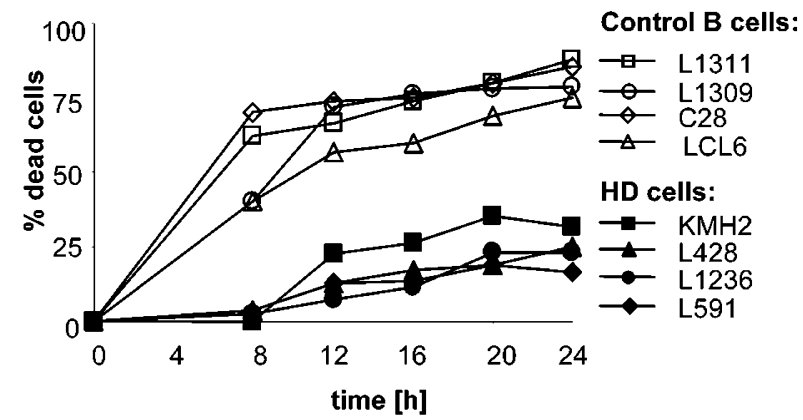

Figure 2 Induction of cell death by staurosporine. Cells were treated for 0 $24 \mathrm{~h}$ with $1 \mu \mathrm{M}$ staurosporine. Cell death was determined by trypan blue exclusion. Each time point represents the average of duplicates 


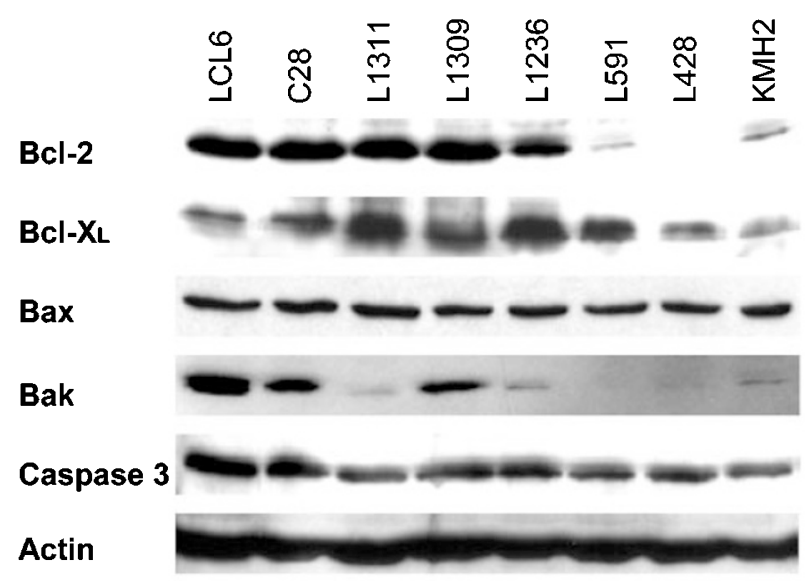

Figure 3 Expression of pro- and antiapoptotic proteins in Hodgkin cell lines. Equal amounts of total cell lysates from the cells indicated were subjected to SDS-PAGE and Western blotting. Proteins were detected after incubation with antibody to $\mathrm{Bcl}-2, \mathrm{Bcl}-\mathrm{X}_{\mathrm{L}}$, Bax, Bak, caspase-3 followed by secondary antibody and ECL as described in Materials and Methods. Equal loading was confirmed by detection of Actin on the same membranes istic sequence of events shown in Figure 1. As shown in Figure 4, staurosporine-treated L591, L1236, L428 and $\mathrm{KMH} 2$ cells do neither show activation of Bax, nor cytochrome $c$ release from the mitochondria or processing of caspase-3. Specifically, Bax activation could hardly be discerned. In contrast, an intact mitochondrial signaling including Bax conformational change, cytochrome $c$ release and caspase-3 processing was observed in L1309, L1311, LCL6 and C28 cells, EBV transformed non-malignant B-cell lines used as control.

To confirm the lack of Bax activation in the HD B-cells, immunofluorescence staining of Bax with anti-Bax $6 \mathrm{~A} 7$, recognizing activated Bax protein, was performed. Figure 5 shows the Bax staining (red) merged with nuclei staining (blue). Consistent with our immunoprecipitation results untreated L1309, L591 and KMH2 cells were negative for staining with 6A7. Treatment of L1309 cells with staurosporine induced a conformational change in Bax, resulting in a punctuated staining pattern ${ }^{12,24}$ as early as $2 \mathrm{~h}$ of treatment, while nuclear fragmentation was observed at later time points in a significant proportion of cells. Neither Bax staining nor nuclear fragmentation was observed in L591 and KMH2 cells after staurosporine treatment up to $12 \mathrm{~h}$, indicating a lack of activated Bax protein and apoptosis.

HD cells:

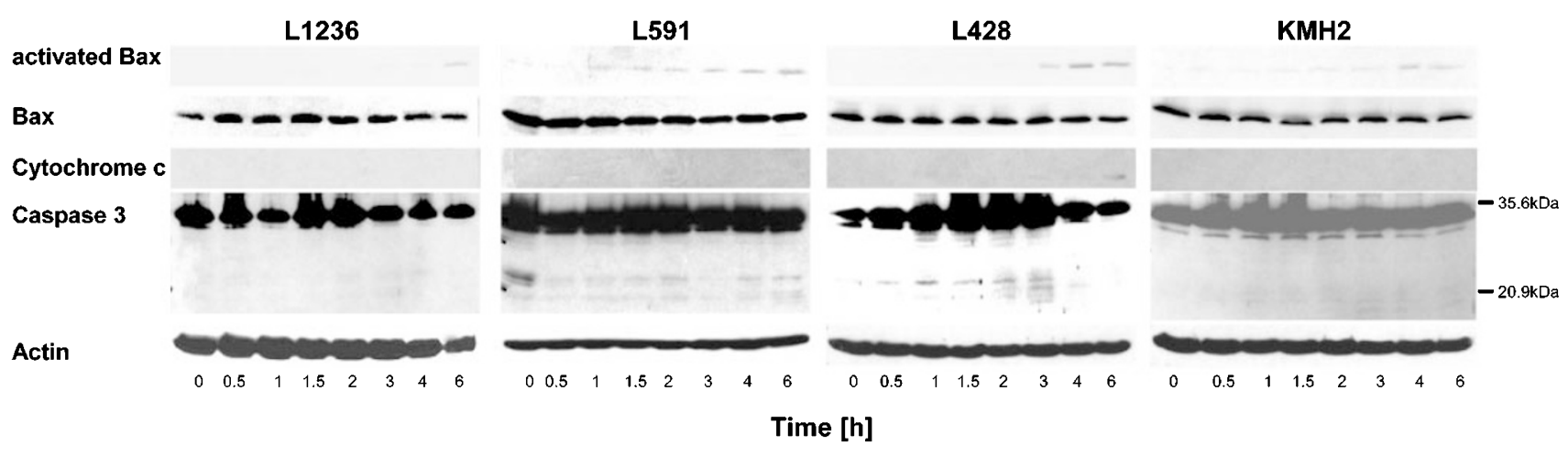

Control B cells:

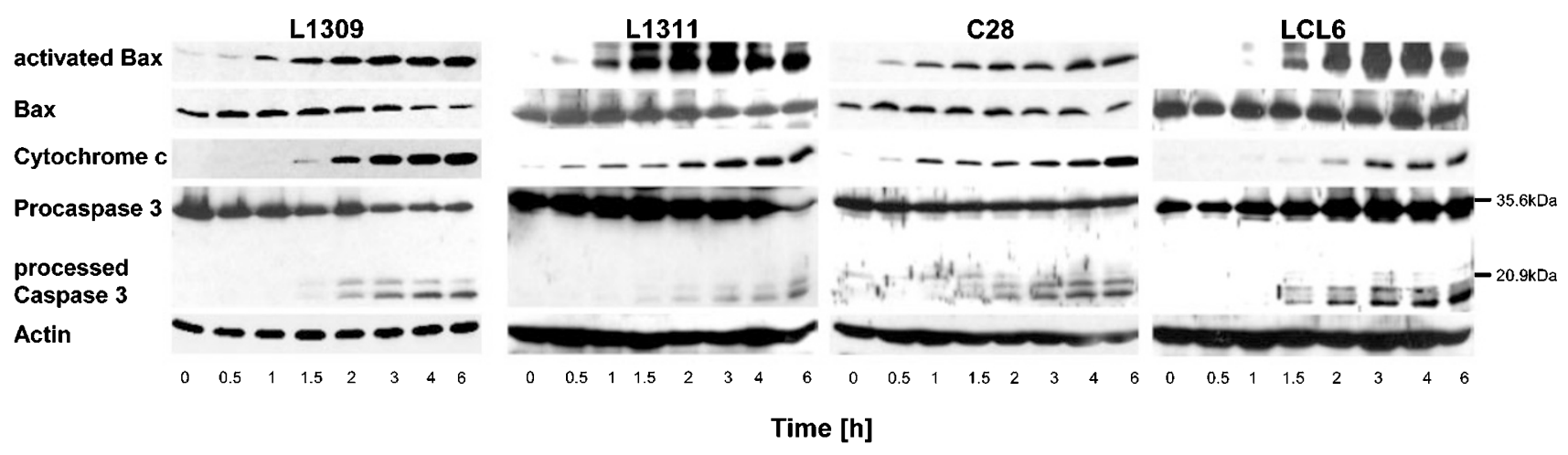

Figure 4 Bax activation, cytochrome $c$ release and caspase activation in Hodgkin and control cell lines. Cells were treated for $6 \mathrm{~h}$ with $1 \mu \mathrm{M}$ staurosporine, aliquots of cell lysates were prepared at the timepoints indicated. Total cell extracts and cytosolic extracts were subjected to SDS-PAGE and Western blotting. Activated Bax was immunoprecipitated in the whole cell extracts with the conformation specific antibody $6 \mathrm{~A} 7$ and subsequently detected by human Bax antiserum and compared to the total amount of Bax in the lysates. Cytochrome $c$ and caspase-3 were detected in cytosolic extracts. Reprobing for Actin ensured equal loading 

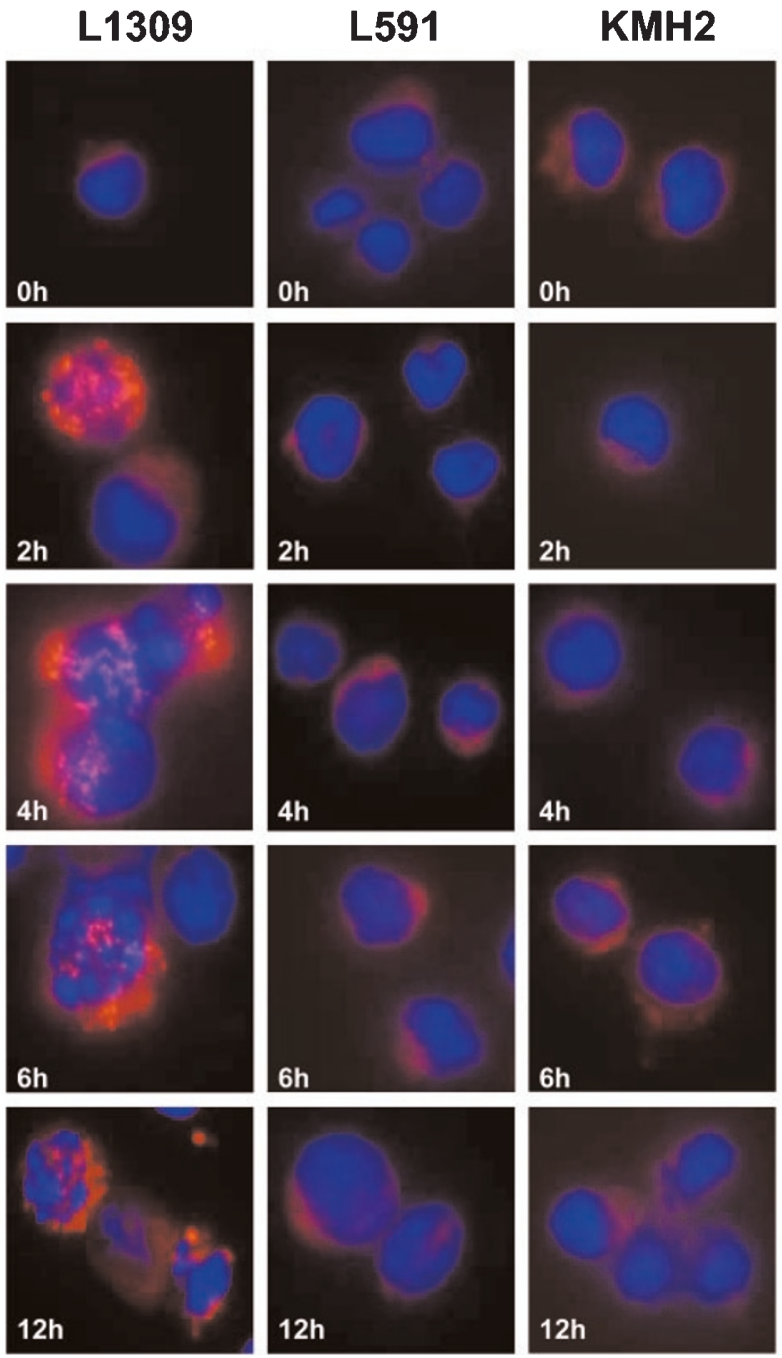

Figure 5 Bax activation by staurosporine-treatment. L1309, L591 and KMH2 cells were treated for $0,2,4,6$ and $12 \mathrm{~h}$ with $1 \mu \mathrm{M}$ staurosporine, and immunostained using $6 \mathrm{~A} 7$ antibody detecting exposure of the Bax $\mathrm{N}$-terminus. Bax $\mathrm{N}$-terminus staining is seen as red fluorescence, nuclei occur blue after counterstaining with Hoechst 33258

\section{Lack of caspase-3 activation in HD B-cells}

The caspase-3 antibody stained some low molecular weight proteins in the cytosolic extracts of L428, L591 and KMH2 cells. These bands do not represent the right size of properly processed caspase-3 and do not suggest enzymatic activity of caspase-3. To rule out the remote possibility of aberrant caspase activation, the activity of caspase-3 was measured by an independent assay system. Caspase activity of cytosolic extracts from L591, L1236, L428, KMH2, L1309, L1311, LCL6, and C28 control cells treated with staurosporine for the times indicated was measured using the fluorogenic substrate DEVD-afc. As shown in Figure 6A, staurosporine-induced caspase activity was only observed in L1309, L1311, LCL6 and C28 control B-cells with a maximum at $6 \mathrm{~h}$ of treatment. No significant activation of caspases could be measured in staurosporine treated L591,
L1236, L428 and KMH2 cells, confirming the results obtained by Western blot analysis.

The possibility of delayed cytochrome $c$ release and caspase-3 processing in HD B-cells compared to the control B-cell line L1309 was ruled out by extended kinetic analysis of cytosolic cytochrome $c$ and caspase-3 processing by Western blotting in parallel to measurements of caspase-3 activation using the fluorogenic substrate DEVDafc (Figure 6b). In the control cell line L1309 the peak activity of caspase-3 was observed $6 \mathrm{~h}$ after induction of apoptosis with staurosporine, decreasing thereafter due to cell death and degradation of the apoptotic cell fragments. Western blotting for proteolytic cleavage during the activation of caspase-3 confirmed the peak of caspase-3 activity at $6 \mathrm{~h}$ of staurosporine treatment. In the staurosporine resistant cell lines, neither cytochrome $c$ release nor proteolytic cleavage and subsequent activity of caspase- 3 could be detected within $24 \mathrm{~h}$ of treatment with staurosporine, indicating that cytochrome $c$ release and caspase-3 activation do not occur at all.

\section{Discussion}

The PKC-inhibitor staurosporine is a classical inducer of apoptosis in a broad spectrum of nontransformed and tumor cells. Four neoplastic B-cell lines established from patients with Hodgkin's disease were shown to be resistant to staurosporine-induced cell death. The results of our study revealed that these $\mathrm{HD}$ B-cell lines have developed a resistance to apoptosis by alteration of the mitochondrial signaling pathway, which manifests in the failure to trigger the release of cytochrome $c$ from mitochondria and subsequent caspase activation. By detailed analysis of the mitochondrial apoptosis pathway the signaling defect was localized upstream of mitochondria at the level of Bax activation.

Hodgkin's disease is a lymphoid neoplasm characterized by low-frequent malignant tumor giant cells, known as $\mathrm{H}$ RS cells, in a background of abundant nonneoplastic inflammatory cells. The HD cell lines used in this study, L428, L591, L1236, and KMH2, are well characterized with regard to their morphology and immunophenotype and display typical B-cell associated markers. ${ }^{25,26}$ For example, immunoglobulin rearrangements were detected in L1236 cells, proving that this cell line is of clonal B-cell origin. ${ }^{18,27}$ Intriguingly, all HD B-cells were resistant to cell death induction by staurosporine and showed a defect in Bax activation, whereas their nonmalignant B-cell counterparts displayed an intact mitochondrial apoptosis pathway. Notably, HDLM2, a Hodgkin cell line of T-cell origin ${ }^{25}$ proved sensitive to staurosporine showing an intact proapoptotic mitochondrial signaling pathway (data not shown). Thus, the defective Bax activation may be restricted to $H D$ tumor cells of the B-cell lineage.

In the HD B-cell lines, Bax activation could be disturbed by a variety of possible mechanisms. The pro-apoptotic protein Bax can not only form homodimers but has also been shown to interact with a variety of other proteins. ${ }^{12,28,29}$ For example, Bax could be bound to antiapoptotic Bcl-2 family members or to presently unknown proteins, masking Bax and preventing its activation. Over- 
A:
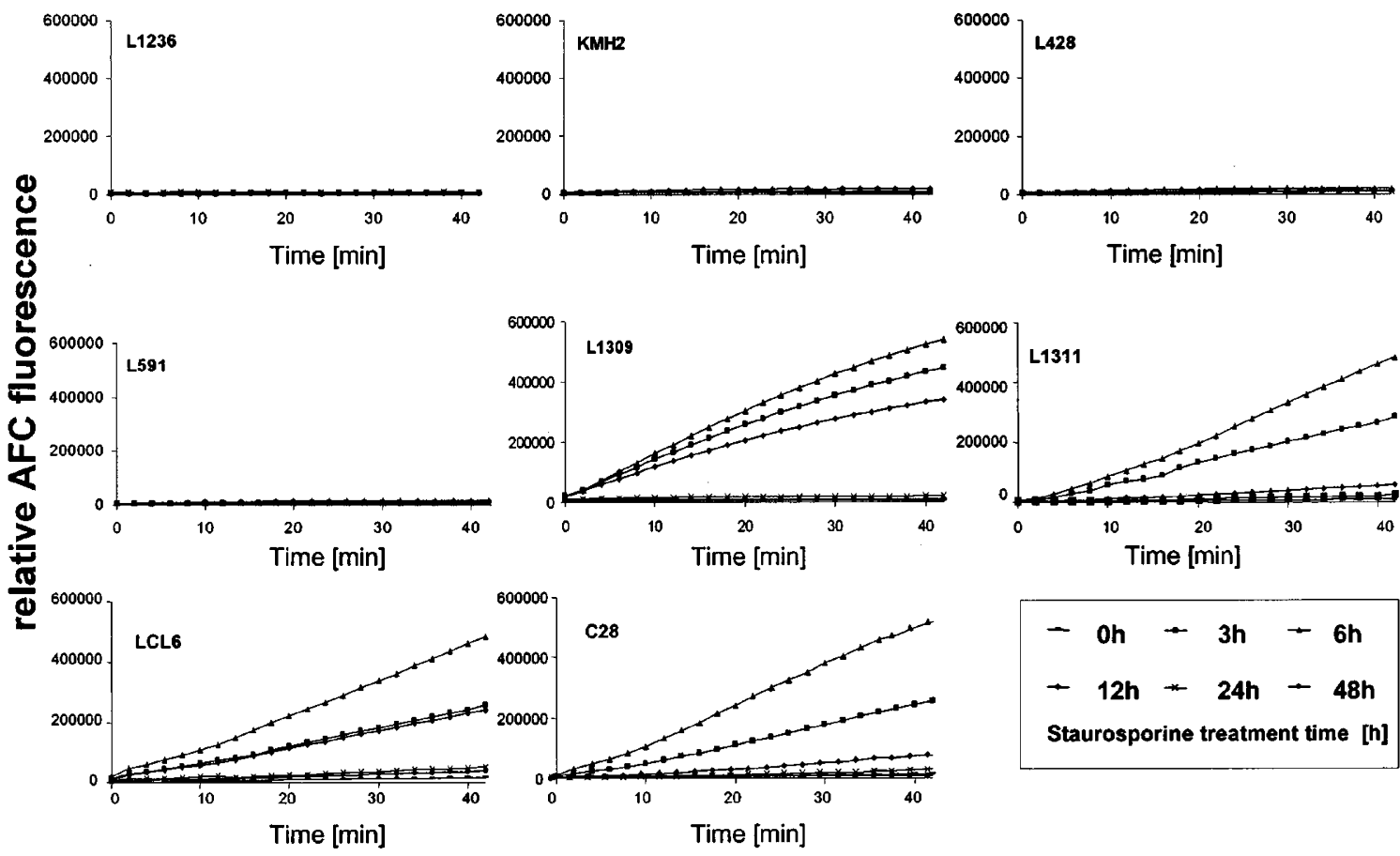

$-0 h \rightarrow 3 h \rightarrow 6 h$

$-12 \mathrm{~h} * 24 \mathrm{~h}-48 \mathrm{~h}$

Staurosporine treatment time [h]

B:

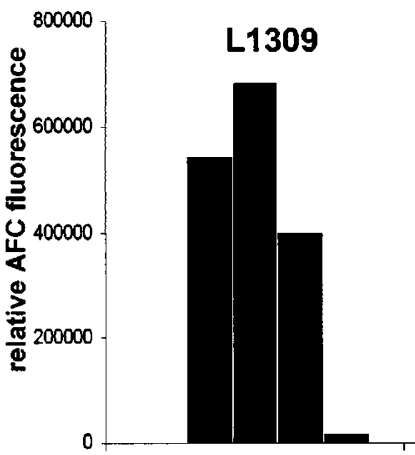

KMH2

L1236

Procaspase 3

active Caspase 3

Cytochrome c
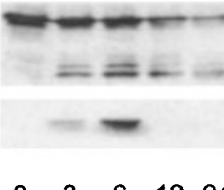

$\begin{array}{lllll}0 & 3 & 6 & 12 & 24\end{array}$

$\begin{array}{lllll}0 & 3 & 6 & 12 & 24\end{array}$

Time [h]

Figure 6 Staurosporine-induced caspase activity. (A) Cells were treated with $1 \mu \mathrm{M}$ staurosporine. Cytosolic extracts were prepared after $0,3,6,12,24$, and $48 \mathrm{~h}$ of treatment. Caspase activity was measured by hydrolysis of DEVD-afc. Samples were normalized for total cytosolic protein content. (B) L1236, KMH2, and L1309 control cells were treated with $1 \mu \mathrm{M}$ staurosporine. Cytosolic extracts were prepared after $0,3,6,12$ and $24 \mathrm{~h}$ of treatment. Caspase activity was measured by hydrolysis of DEVD-afc. Samples were normalized for total cytosolic protein content. Cytosolic extracts were also subjected to SDS - PAGE and Western blotting. Cytochrome $c$ and caspase- 3 were detected in cytosolic extracts

expression of Bcl-2 and Bcl- $\mathrm{X}_{\mathrm{L}}$, for example, can inhibit Bax function and cytochrome $c$ release from mitochondria, which subsequently leads to a failure to activate the executioner caspases. 
Staurosporine has been shown to block PKC-mediated $\mathrm{Bcl}-2$ phosphorylation in vitro. ${ }^{30,31} \mathrm{Bcl}-2$ phosphorylation at the evolutionarily conserved serine- 70 residue seems to be required for its anti-apoptotic function and may affect the stability of interaction with Bax. ${ }^{30}$ Thus, a failure of staurosporine to block Bcl-2 phosphorylation would be one possible explanation for the lack of Bax activation in HD B-cells. However, significant differences in the level of phosphorylated Bcl-2 in HD B-cells compared to control cells could not be detected before or after staurosporine treatment (data not shown). In addition, compared to control B-cells, Bcl-2 and Bax proteins did not coprecipitate in HD cells at particularily high levels, indicating that Bax is apparently not inhibited by $\mathrm{Bcl}-2$ in these cells (data not shown). This is in line with the observation that $\mathrm{Bcl}-2$ is expressed at lower levels in HD B-cells (Figure 3).

Apoptosis pathways consist of a cascade of signaling proteins before the final irreversible decision to die is made. The whole pathway is tightly regulated by a variety of proteins, as are the members of the Bcl-2 family, the inhibitors of apoptosis (IAPs), and the Smac/Diabolo proteins. $^{32-35}$ Therefore, resistance to apoptosis can be acquired by regulation of different steps in the pathway. Cells lacking both Bax and Bak are completely resistant to multiple apoptotic stimuli such as staurosporine, ultraviolet radiation, growth factor deprivation, etoposide and endoplasmic reticulum stress stimuli. ${ }^{36}$

Like HD B-cell lines, most HD biopsies however, stained positive for Bax and/or Bak. ${ }^{37-41}$ This leads to the conclusion that the cell death promoting activity of Bax might be neutralized by other apoptosis regulating proteins. $^{38}$ Besides Bcl-2, HD B-cells expressed Bcl- $\mathrm{X}_{\mathrm{L}}$, another anti-apoptotic member of the Bcl-2 family. Bcl- $\mathrm{X}_{\mathrm{L}}$ expression has been previously observed by immunohistochemical analysis of $\mathrm{HD}$ biopsies. However, $\mathrm{Bcl}-\mathrm{X}_{\mathrm{L}}$ is also expressed by nonmalignat B-cells. Furthermore, Bcl- $X_{L}$ has not been shown to be a target for staurosporine. Clearly, the molecular mode of staurosporine action and, in particular, its failure in HD B-cells has yet to be elucidated.

In many tumors, resistance to apoptosis was shown to be secondary to high levels of anti-apoptotic Bcl-2-like proteins and/or low level expression of their pro-apoptotic counterparts. In HD B-cells the balance of pro- and antiapoptotic $\mathrm{Bcl}-2$ proteins is apparently not disturbed. Rather, HD B-cells provide the first example for a tumor entity, where resistance to mitochondrial apoptosis seems to be brought about by a regulatory defect controlling Bax activation.

\section{Materials and Methods}

\section{Cell culture}

The establishment of the Hodgkin B-cell lines L591, L428, L1236 and $\mathrm{KMH} 2$ has been described elsewhere. ${ }^{25,42}$ The HD cell lines and L1309, L1311 were a gift of V Diehl; LCL6 a gift of M Kochanek; C28 a gift of $\mathrm{H}$ Abken, University of Köln, Germany. The control B cell lines were established by immortalization of human primary B-cells by EBV. The cell lines were cultured in VLE RPMI 1640 (Biochrom) supplemented with 10\% FCS (Biochrom), 2 mM L-glutamine, $100 \mu \mathrm{g} / \mathrm{ml}$ streptomycin and $100 \mathrm{U} / \mathrm{ml}$ penicillin. Apoptosis was induced by incubating the cells in the presence of $1 \mu \mathrm{M}$ staurosporine (Alexis). Cell death was examined using trypan blue exclusion. All chemicals were purchased from Sigma unless indicated otherwise.

\section{Sample preparation and immunoblotting}

For isolation of cytosolic extracts, $10^{7}$ cells were washed twice with PBS at $4^{\circ} \mathrm{C}$. Cells were resuspended in $50 \mu$ of buffer A $(50 \mathrm{mM}$ PIPES, pH 7.0, $50 \mathrm{mM} \mathrm{KCl}, 2 \mathrm{mM} \mathrm{MgCl}$, $5 \mathrm{mM}$ EGTA, $10 \mu \mathrm{M}$ cytochalasin $\mathrm{B}$, protease inhibitors (protease complete cocktail: $15 \mu \mathrm{g} / \mathrm{ml}$ pancreatic extract; $15 \mu \mathrm{g} / \mathrm{ml}$ pronase; $0.8 \mu \mathrm{g} / \mathrm{ml}$ thermolysin; $1.5 \mu \mathrm{g} / \mathrm{ml}$ chymotrypsin; $0.2 \mathrm{mg} / \mathrm{ml}$ trypsin; $1 \mathrm{mg} / \mathrm{ml}$ papain; Roche Diagnostics) and $1 \mathrm{mM}$ dithiothreitol and incubated for $20 \mathrm{~min}$ on ice for swelling. After addition of mannitol and sucrose to a final concentration of $220 \mathrm{mM}$ and to $68 \mathrm{mM}$ respectively, cells were cracked by passing through a 27 -gauge needle. Cell breakage was verified microscopically using trypanblue exclusion. Membranes were pelleted at $14000 \times g$ for $20 \mathrm{~min}$ at $4^{\circ} \mathrm{C}$, and the resulting supernatants recovered (cytosolic extract). Whole cell extracts were prepared by lysing $10^{7}$ cells in $1 \mathrm{ml}$ of CHAPS lysis buffer (10 mM HEPES, pH 7.4, $150 \mathrm{mM} \mathrm{NaCl}, 1 \%$ CHAPS, protease complete cocktail) on ice for $30 \mathrm{~min}$. The crude lysate was then centrifuged at $14000 \times \mathrm{g}$ for $20 \mathrm{~min}$ at $4{ }^{\circ} \mathrm{C}$ and the supernatant stored at $-80^{\circ} \mathrm{C}$. Equal volumes of cytosol and whole cell extract were separated by SDS-PAGE and transferred to nitrocellulose membrane (Protran $0.2 \mu \mathrm{m}$; Schleicher and Schuell). Rabbit polyclonal antisera specific for human caspase-3, human Bax, $\mathrm{Bak}, \mathrm{Bcl}-\mathrm{X}_{\mathrm{L}}$ and monoclonal mouse anti-cytochrome $c$ were obtained from Pharmingen. The polyclonal anti-serum specific for $\mathrm{Bcl}-2$ was a gift from J C Reed, La Jolla, USA. Horseradish peroxidase conjugates of anti-rabbit and anti-mouse IgG (Biorad) were used as secondary antibodies and signals were detected by ECL (Amersham).

\section{Immunoprecipitation}

Equal volumes of whole cell lysates $\left(10^{7} \mathrm{cells} / \mathrm{ml}\right)$ were used for immunoprecipitation. The $\mathrm{KCl}$ concentration of the cell lysates was adjusted to $150 \mathrm{mM}$, and all samples were brought to a final volume of $500 \mu \mathrm{l}$ with CHAPS lysis buffer. Samples were rotated for $12 \mathrm{~h}$ at $4^{\circ} \mathrm{C}$ with $6 \mu \mathrm{g}$ of monoclonal anti-Bax 6A7 antibody (Pharmingen). Antigenantibody complexes were immobilized by rotation for $2 \mathrm{~h}$ at $4{ }^{\circ} \mathrm{C}$ with GammaBind G Sepharose (Pharmacia Biotech). The complexes were pelleted $(1 \mathrm{~min}, 14000 \times \mathrm{g})$ and the supernatant removed. The complexes were then washed three times with the same buffer used for the immunoprecipitation and subjected to SDS-PAGE and immunoblotted as described above.

\section{Immunofluorescence and fluorescence microscopy}

Cells were treated with $1 \mu \mathrm{M}$ staurosporine for $0,2,4,6$ and $12 \mathrm{~h}$, harvested and washed twice with cold PBS. Cells were then fixed with $3 \%$ paraformaldehyde for $20 \mathrm{~min}$, permeabilized with $0.1 \%$ saponin in PBS for $10 \mathrm{~min}$, and blocked with 3\% BSA, $0.005 \%$ sodium azid, $4 \mu \mathrm{l} /$ $\mathrm{ml}$ gelatine (45\% Teleostean gelatine) and $0.1 \%$ saponin in PBS for $30 \mathrm{~min}$. For immunostaining, cells were incubated with primary mouse anti-Bax $6 \mathrm{~A} 7$ antibody for $1 \mathrm{~h}$, washed with $0.1 \%$ saponin in PBS and then incubated with goat anti-mouse antibody conjugated with Alexaflour 568 (Molecular Probes) for $30 \mathrm{~min}$. Nuclei were counterstained with Hoechst $33258(10 \mu \mathrm{g} / \mathrm{ml}$ PBS) and mounted on glass slides and examined under a fluorescence microscope. 


\section{Preparation of cytosolic extracts and caspase activation}

For preparation of cell free lysates the procedure described by Ellerby et al. (1997), and Stennicke et al. (1998) ${ }^{43,44}$ was used with minor modifications. $10^{7}$ cells were harvested, washed twice in phosphatebuffered saline at $4{ }^{\circ} \mathrm{C}$, pelleted for $5 \mathrm{~min}$ at $1200 \times \mathrm{g}$ and resuspended in HEB (20 mM PIPES, pH 7.0, $50 \mathrm{mM} \mathrm{KCl}, 2 \mathrm{mM} \mathrm{MgCl}, 5 \mathrm{mM}$ EGTA, $1 \mathrm{mM}$ dithiothreitol) and allowed to swell on ice for $20 \mathrm{~min}$. After addition of PMSF to $100 \mu \mathrm{M}$, cells were cracked by passing through a 27 -gauge needle and pelleted at $14000 \times g$ for $20 \mathrm{~min}$ at $4^{\circ} \mathrm{C}$. The resulting supernatant (cytosolic extract) was recovered. Protein concentration was determined by the bicinchroninic acid assay method (Pierce) using BSA as a standard. Protein concentrations of extracts were adjusted to $2 \mathrm{mg} / \mathrm{ml}, 5 \mu$ l of cytosolic extract were added to $95 \mu$ l caspase buffer (20 mM Pipes, $100 \mathrm{mM} \mathrm{NaCl}, 1 \mathrm{mM}$ EDTA, $0.1 \%$ CHAPS, $10 \%$ sucrose, $10 \mathrm{mM}$ dithiothreitol) and reactions were initiated by addition of $100 \mu \mathrm{M}$ Ac-DEVD-AFC (Ac-DEVD-7-amino-4trifluoromethyl coumarin). Caspase activity was assayed by release of 7-amino-4-trifluoromethyl-coumarin (AFC) from DEVD containing synthetic peptides using continuous-reading plate reader (Wallac victor ${ }^{2} \mathrm{TM}$ multilabel counter 1420 ) thermostated at $30^{\circ} \mathrm{C}$ at $400 /$ $505 \mathrm{~nm}$ excitation and emission respectively.

\section{Acknowledgements}

The authors would like to thank V Diehl, A Staratschek-Jox, H Abken and M Kochanek, Köln, Germany, for cell lines and helpful discussions, O Krut for helpful discussions and JC Reed, La Jolla, USA, for polyclonal antibodies. The support of the Deutsche Forschungsgemeinschaft, Deutsche Krebshilfe and Köln Fortune is kindly acknowledged.

\section{References}

1. Nicholson DW (1996) ICE/CED3-like proteases as therapeutic targets for the control of inappropriate apoptosis. Nat. Biotechnol. 14: 297-301

2. Thornberry NA and Lazebnik Y (1998) Caspases: enemies within. Science 281: $1312-1316$

3. Nicholson DW (1999) Caspase structure, proteolytic substrates, and function during apoptotic cell death. Cell Death Differ. 6: 1028-1042

4. Ashkenazi A and Dixit VM (1999) Apoptosis control by death and decoy receptors. Curr. Opin. Cell Biol. 11: 255-260

5. Li P, Nijhawan D, Budihardjo I, Srinivasula SM, Ahmad M, Alnemri ES and Wang X (1997) Cytochrome $c$ and dATP-dependent formation of Apaf-1/Caspase-9 complex initiates an apoptotic protease cascade. Cell 91: 479-489

6. Green DR and Reed JC (1998) Mitochondria and apoptosis. Science 281 : $1309-1312$

7. Reed JC, Jürgensmeier JM and Matsuyama S (1998) Bcl-2 family proteins and mitochondria. Biochim. Biophys. Acta 1366: 127-137

8. Kluck RM, Bossy-Wetzel E, Green DR and Newmeyer DD (1997) The release of cytochrome c from mitochondria: a primary site for $\mathrm{Bcl}-2$ regulation of apoptosis. Science 275: $1132-1136$

9. Jürgensmeier JM, Xie Z, Deveraux Q, Ellerby L, Bredesen D and Reed JC (1998) Bax directly induces release of cytochrome $\mathrm{c}$ from isolated mitochondria. Proc. Natl. Acad. Sci. 95: 4997-5002

10. Wolter KG, Hsu YT, Smith CL, Nechushtan A, Xi XG and Youle RJ (1997) Movement of Bax from the cytosol to mitochondria during apoptosis. J. Cell Biol. 139: $1281-1292$

11. Nechushtan A, Smith CL, Hsu YT and Youle RJ (1999) Conformation of the Bax C-terminus regulates subcellular location and cell death. EMBO J. 18: 2330 2341
12. Murphy KM, Ranganathan V, Farnsworth ML, Kavallaris M and Lock RB (2000) $\mathrm{Bcl}-2$ inhibits Baxtranslocation from cytosol to mitochondria during drug-induced apoptosis of human tumour cells. Cell Death Differ. 7: 102-111

13. Eskes R, Desagher S, Antonsson B and Martinou JC (2000) Bid induces the oligomerization and insertion of Bax into the outer mitochondrial membrane. Mol. Cell Biol. 20: 929-935

14. Hsu Y-T and Youle R (1998) Bax in murine thymus is a soluble monomeric protein that displays differential detergent-induced conformations. J. Biol. Chem. 273: 10777-10783

15. Hsu Y-T and Youle R (1997) Nonionic detergents induce dimerization among members of the Bcl-2 family. J. Biol. Chem. 272: 13829-13834

16. Tsujimoto $Y$, Cossman J, Jaffe $E$ and Croce $C$ (1985) Involvement of the bcl-2 gene in human follicular lymphoma. Science 228: 1440-1443

17. Cleary ML, Smith SD and Sklar J (1986) Cloning and structural analysis of cDNAs for bcl-2 and a hybrid bcl-2/immunoglobulin transcript resulting from the $t(14 ; 18)$ translocation. Cell $47: 19-28$

18. Vaux DL, Cory S and Adams J (1988) Bcl-2 gene promotes haemopoietic cell survival and cooperates with c-myc to immortalize pre-B cells. Nature 335: $440-$ 442

19. Küppers R (1999) Identifying the precursors of Hodgkin and Reed-Sternberg cells in Hodgkin's disease: role of the germinal center in B-cell lymphomagenesis. J. Aquir. Immune Defic. Syndr. 21 (Suppl 1): 74-79

20. Tang D, Okada H, Ruland J, Liu L, Stambolic V, Mak TW and Ingram AJ (2001) Akt Is Activated in Response to an Apoptotic Signal. J. Biol. Chem. 276: 30461 30466

21. Desagher S, Osen-Sand A, Nichols A, Eskes R, Montessuit S, Lauper S, Maundrell K, Antonsson B and Martinou JC (1999) Bid-induced conformational change of $\mathrm{Bax}$ is responsible for mitochondrial cytochrome $\mathrm{c}$ release during apoptosis. J. Cell Biol. 144: $891-901$

22. Stepczynska A, Lauber K, Engels IH, Janssen O, Kabelitz D, Wesselborg S and Schulze-Osthoff K (2001) Staurosporine and conventional anticancer drugs induce overlapping, yet distinct pathways of apoptosis and caspase activation. Oncogene 20: 1193-1202

23. Perez D and White $E(2000)$ TNF- $\alpha$ signals apoptosis through a Bid-dependent conformational change in Bax that is inhibited by E1B 19K. Mol. Cell 6: 53-63

24. Makin GWJ, Corfe BM, Griffiths GJ, Thistlethwaite A, Hickman JA and Dive C (2001) Damage-induced Bax N-terminal change, translocation to mitochondria and formation of Bax dimers/complexes occur regardless of cell fate. EMBO J. 20: $6306-6315$

25. Drexler HG (1993) Recent results on the biology of Hodgkin and ReedSternberg cells. II. Continuous cell lines. Leukemia and Lymphoma 9: 1-25

26. Stein H, Diehl V, Marafioti T, Jox A, Wolf J and Hummel M (1999) The nature of Red-Sternberg cells, lymphocytic and histiocytic cells, and their molecular biology in Hodgkin's disease. In: Hodgkin's Disease, Mauch PM, Armitage JO, DiehI V, Hoppe RT and Weiss LM, eds (Philadelphia, PA: Lippincott Williams and Wilkins) pp. 121-137

27. Kanzler H, Hansmann ML, Kapp U, Wolf J, Diehl V, Rajewsky K and Küppers R (1996) Molecular single cell analysis demonstrates the derivation of a peripheral blood-derived cell line (L1236) from the Hodgkin/Reed-Sternberg cells of a Hodgkin's lymphoma patient. Blood 87: 3429-3436

28. Korsmeyer SJ (1995) Regulators of cell death. Trends Genet. 11: 101-105

29. Martinou JC (1999) Apoptosis. Key to the mitochondrial gate. Nature 399: $411-412$

30. ItoT, Deng X, Carr B and May WS (1997) Bcl-2 phosphorylation required for anti-apoptosis function. J. Biol. Chem. 272: 11671-11673

31. Deng X, Ruvolo P, Carr B and May Jr WS (2000) Survival function of ERK $1 / 2$ as IL-3-activated, staurosporine-resistant Bcl-2kinases. Proc. Natl. Acad. Sci. USA 97: $1578-1583$

32. Reed JC (1998) Bcl-2 family proteins. Oncogene 17: 3225-3236

33. Devereaux QL and Reed JC (1999) IAP family proteins- suppressors of apoptosis. Genes Dev. 13: 239-252

34. Verhagen AM, Ekert PG, Pakusch M, Silke J, Connolly LM, Reid GE, Moritz RL, Simpson RJ and Vaux DL (2000) Identification of DIABLO, a mammalian protein that promotes apoptosis by binding to and antagonizing IAP proteins. Cell 102: $43-53$ 
35. Du C, Fang M, Li Y, Li L and Wang X (2000) Smac, a mitochondrial protein that promotes cytochrome c-dependent caspase activation by eliminating IAP inhibition. Cell 102: 33-42

36. Wei MC, Zong WX, Cheng EH, Lindsten T, Panoutsakopoulou V, Ross AJ, Roth KA, MacGregor GR, Thompson CB and Korsmeyer SJ (2001) Proapoptotic BAX and BAK: a requisite gateway to mitochondrial dysfunction and death. Science 292: $727-730$

37. Reed JC, Miyashita T, Krajewski S, Takayama S, Aime-Sempe C, Kitada S, Sato T, Wang H-G, Harigai M, Hanada M, Krajewska M, Kochel K, Millan J and Kobayashi $\mathrm{H}$ (1996) Bcl-2 family proteins and the regulation of programmed cell death in leukemia and lymphoma. Cancer Treat Res. 84: 31-72

38. Brousset $P$, Benharroch D, Krajewski S, Laurent G, Meggetto F, Rigal-Huguet $F$, Gopas J, Prinsloo I., Pris J, Delsol G, Reed JC and Schlaifer D (1996) Frequent expression of the cell death-inducing gene Bax in Reed-Sternberg cells of Hodgkin's disease. Blood 87: 2470-2475

39. Schlaifer D, Krajewski S, Rigal-Huguet F, Laurent G, Pris J, Delsol G, Reed JC and Brousset $P$ (1997) Bcl-X gene expression in Hodgkin's disease. Leukemia and Lymphoma 23: $143-146$

40. Chu WS, Aguilera NSI, Wie MQ and Abbondanzo SL (1999) Antiapoptotic marker, Bcl- $\mathrm{X}_{\mathrm{L}}$, expression on Reed-Sternberg cells of Hodgkin's disease using a novel monoclonal marker, YTH-2H12. Human Pathology, 30: 1065-1070
41. Kanavaros P, Stefanaki K, Vlachonikolis J, Eliopoulos G, Kakolyris S Rontogianni D, Gorgoulis V and Georgoulias V (2000) Expression of p53, p21/ waf1, bcl-2, bax, RB and Ki67 proteins in Hodgkin's lymphomas. Histol. Histopathol. 15: 445-453

42. Wolf J, Kapp U, Bohlen H, KornackerM, Schoch C, StahlB, Mucke S, von Kalle C Fonatsch C, Schaefer HE, Hansmann ML and DiehI V (1996) Peripheral blood mononuclear cells of a patient with advanced Hodgkin's lymphoma give rise to permanently growing Hodgkin-Reed Sternberg cells. Blood 87: 3418-3428

43. Ellerby HM, Martin SJ, Ellerby LM, Naiem SS, Rabizadeh S, Salvesen G Casiano CA, Cashmann NR, Green DR and Bredesen DE (1997) Establishment of a cell-free system of neuronal apoptosis: comparison of premitochondrial, mitochondrial, and postmitochondrial phases. J. Neurosci. 17: 6165-6178

44. Stennicke HR, Jürgensmeier JM, Shin H, Deveraux Q, WolfBB, Yang X, Zhou Q, Ellerby HM, Ellerby LM, Bredesen D, Green DR, Reed JC, Froelich CJ and Salvesen GS (1998) Pro-caspase-3 is a major physiologic target of caspase-8. J. Biol. Chem. 273: $27084-27090$ 